\title{
The Case of Turkey as an EU Member State Candidate: Evolving the Cosmopolitan Enlightened HyperCitizen European Union ${ }^{1}$
}

\author{
Andrea Pitasi ${ }^{1 *}$, Sara Petroccia ${ }^{1}$, Camila Giovana Portolese ${ }^{2}$, and \\ Gyorgy Csepeli ${ }^{3}$
}

${ }^{1}$ University d'Annunzio, Chieti-Pescara, Italy
${ }^{2}$ University of Leiden, Leiden, the Netherlands
${ }^{3}$ Iask, Koszeg, Hungary
${ }^{*}$ Correspondent author: Andrea Pitasi - pitasigda@gmail.com

Received: 31. 08. 2020; Accepted: 20. 11. 2020; Published: 20. 12. 2020

DOI: https://doi.org/10.46473/WCSAJ27240606/20-12-2020-0024

Category: Research paper

\begin{abstract}
This is a legal and political sociology essay with the objective of a strategic geopolitical, legal and economic analysis of the pros and cons of Turkey's potential entry as a member state of the European Union. The essay is placed on the side of the policies, more in detail on the side of politics making, it starts with the analysis of the state of art, to move towards the need for structural coupling between Turkey and the European Union and then - lastly- there are some authors' thoughts on a potential eastward enlargement of the European Union with its pros and its cons.
\end{abstract}

Keywords: Turkey, European Union, Policy making, Hypercitizenship, Guidelines

\section{Prologue}

The concept of Europe as a matter of fact is extremely flexible at least for the colonial and postcolonial interconnections with the rest of the world. The recovery of institutional sovereignty never meant the making of a new civilization or of a local culture whatever it means. There is no Portugal free Brazil, no Spain free Argentina, no Dutch free South Africa, no French free Congo, but also no Precolombian civilization free Europe for example, no China or Japan free Holland and so on. Memes (Dawkins,1976) cross-fertilize, new interconnected shapes emerge. The numbers we currently use are Indians imported West by the Arabs, a paper we write on is a Chinese invention (Gombrich,1985). If we search for the local and typical and for ontological borders we find nothing. The European Union moreover is not a synonym of Europe. It is an artificial Leviathan born on technical requirements and

\footnotetext{
${ }^{1}$ The study has been presented at 4 th International on-line scientific conference Russia and the west: topical issues of sociology, political science and international relations in the era of globalization, Izhevsk, Udmurt State University, 29. 11. 2020.
} 
institutional needs to guarantee peaceful cooperation and trades on a global scale after the WWII tragedies. EU became more and more artificial, cosmopolitan and open through global trade of intangibles but also through peaceful life quality standards like the human rights of the Treaty of Nice. Thus identity, culture, civilization, localism, nationalism and so on are not relevant for letting Turkey in /out of the EU. EU is an evolution of cosmopolitan Enlightenment (as discussed in the next paragraphs) thus religion is not a difference which makes the difference, pivotal instead the fact the human right standards are respected by all the member states and would-be ones. Moreover, if the OECD - EU shared agenda and policy keep on co-evolving as they are doing, a wider, more complex, cosmopolitan and open global player might take shape and the embedment of Turkey in it might be even esier but it is just a futurology thought, now let us focus on the next steps of the road ahead reminding Boatca's concept of "Otherwise Europe" (Boatcă et al., 2016): which is strategic to understand shifting, memetic identities not interested in rigid jails.

More Globalization means more globalization, more nationalism means more globalization due to the principle of continuous memetic recombination and reconfiguration.

Since Erdogan's rise to power, social and political sciences were under attack of dramatic public funding cuts and more but not for the reasons the media sometimes represented: Erdogan's nationalistic party was not worried about social scientists educated as critical thinkers, mass protesters: much ado about nothing as Luhmann already taught in his "Ecological Communication" (Luhmann, 1989), Erdogan was and is scared because research determines policy which determines politics as taught Lowi in "Arenas of Power" (Lowi, 2009). What is scaring for totalitarian powers is an outcome of science which was and is this work vision by providing a research based policy guidelines about a potential structural coupling between the European Union and Turkey.

\section{Methodology Evolves, Identity Expands}

The national outlook is considered a very primitive and cognitive saving form of the most ancient and darkest side of our species evolution and the most elementary tool for trivial common sense to redraw old boundaries and rebuild old walls, boundaries, and walls totally meaningless and useless in global and cosmopolitan age, hypercitizens already practice but still demanded as fetish symbols and dead myths shaped as Linus's blanket by the least civilized and tribal configurations of our species on our planet nowadays. For example, the trans nationalization of capitals (Plüss, 2013, 4-7) is pivotal to witness the end of the national outlook nevertheless this trans nationalization is possible only after capitals are fully dematerialized into intangible asset portfolios (Pitasi and Ferone, 2008). The national outlook was based on a strong and linear idea of culture, usually, the one taught in the history high school lessons in the 1950s culture is a very tricky piece of obsolete (i.e. obsolete knowledge) in the cosmopolitan complexity age in which the current systemic paradigm after the postparsonsian shift inspired by Luhmann's "Warum AGIL?" (Luhmann, 1988, 1990, 1995, 1997 and 2010) may consider "culture" as an enormous constellation of cosmopolitan, memetic recombination's and reconfigurations on a global scale and no longer the reproduction generation by generation of behavior, opinions and attitudes shaped by tradition though the ages with no effective chance of meaningful change. The national look culture-based leads both to the Malthus Trap (Malthus, 2004) and to the Obsoledge Trap described by Toffler and Toffler (2006, 111-114). The transnational flow of migrant labor produces itself the Obsolete Trap as an increase of circulating labor masses might very unlikely be led to a capital 
improvement. Dematerialization and the trans nationalization of capitals leas out of the Malthus and Obsolete traps that are why, as clearly developed by Xiaoying Qi (2012, 707723) the dematerialized flow par excellence is knowledge and sometimes globalization simply means to let just one concept flow transnationally, redesigning global thinking. Malthus Trap is founded on a very simple and powerful statement: "population, when unchecked, increased in a geometrical ratio and subsistence for man in an arithmetical ratio" (Malthus, 2004, 21) which means that when the population growth speed (PGS) is faster than the subsistence growth speed (SGS) PGS > SGS, the Malthus Trap is unavoidable and only high speed, radical, reconfiguration technological change can artificially turn upside down this "natural selection" implied by: PGS > SGS to SGS > PGS.

It is taken for granted that Malthus (1766-1834) could never read Darwin's (1809-1882) "On The Origin of Species" (1859), nevertheless these two authors dramatically influenced what thinking scientifically means: coping with the blindness of evolution which shapes social free energy (SGS > PGS) and social entropy (PGS > SGS) or, in other words, variety (SGS > PGS) and density (PGS > SGS). As sketched out above, for example, an increasing gagging and a higher birth rate do not represent the problem (aging) and its solution (new born reduce the average age), they converge paradoxically in a bigger problem: the Malthus Trap. Likewise, protecting and conserving memory, human heritage while also improving radical scientific and technological reconfigurations do not represent the problem (the old) and its solution (the emerging new) but still represent a bigger problem: the expanding obsoledge as adapting the new to the old simply generates the inflation of the old. The theorem consists in this: the systemic evolution of mankind on Earth affects individual choices and experiences at the key bifurcation kunhnian revolutionary challenges (Pitasi, 2011a, 2011b, 2012a, 2012b, 2012c) and apparently do not in Kuhn's normality as social life is made of cows Ortega y Gasset, 1963). Individual choices and experiences do not affect systemic evolution with the unique effect of the high resonance traffic jam noise paradox which witnesses that individual influences on systemic evolution are blind. The traffic jam paradox shows that by interviewing the City Major, the City Traffic Manager, the Municipality Hall Policemen, the individuals sitting in their cars in the jam none of them will tell you that the traffic jam is the outcome of their intentions, ideas, values etc. The Traffic Jam Paradox can be easily applied to all people supporting an ecological - green vision: none of them will tell you that the Malthus Trap (the Traffic Jam) emerges from their intentions, ideas, values, choices which are focused on a cleaner planet. Nevertheless, a more ecological social order would dive into the Malthus Trap if ecological choices dramatically influence the rapport between world population demographic growth (WPDG or, as above, PGS) and Evolutionary Resource Reproduction Speed (ERRS or, as above, SGS).

If WPDG/PGS = ERSS/SGS the trap is already open to let our species enter.

If WPDG/PGS>ERSSS/SGS our species is already in the trap.

Once again, in logic-deductive terms, the exit from the trap is an evolutionary systemic bifurcation:

1. The making of a Malthusian vision i.e. high quality eco-bio food in a ridiculous amount which imply million and million people fighting for just "one tomato"; or 
2. A convergent tech reconfiguration evolving capital (genetic, information \& more) independently from worked joule which is the logic solution provided by the theorem provided in this essay.

Figure 1 below (designed by Pitasi describes the shape of the bifurcation while Figures 2 and 3) describe some resource reallocation trends on a global scale up to 2050 (cfr. Smith 2011, 178 and 193). Figure 4 pictures Pearce's hypothesis on population crash (Pearce, 2010, 1-2) which would, at a first and misleading glance, falsify the bifurcation trend described above. Taking Pearce's hypothesis for granted as a "simulation model" it does not falsify the bifurcation, it rather seems to describe the mildest "day after" scenario of the option A of the bifurcation itself nevertheless Pearce's works seems to be focus on a technological coteries paribus while from now on to 2050 (and over) the reconfigurational power of convergent technologies is already huge (Harris, 2007; Rose, 2009) and this methodological mistake seems to dramatically reduce Pearce's hypothesis reliability. The bifurcation in which we found a systemic theory of global evolution.

\section{SYSTEMIC THEOREM OF GLOBAL EVOLUTION}

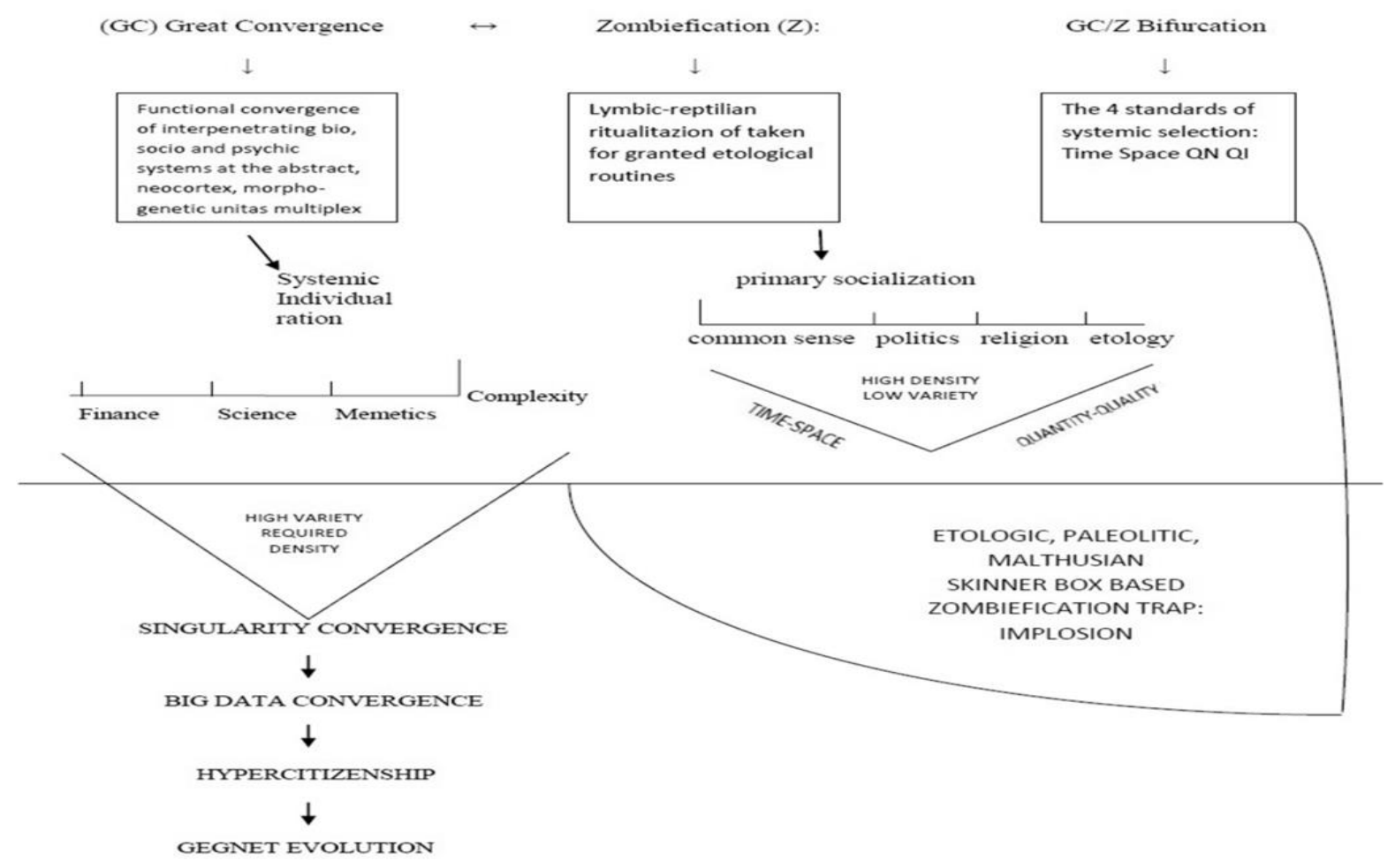

Figure 1. Pitasi's elaboration from the Smith (2011). 
WORLD COMPLEXITY SCIENCE ACADEMY JOURNAL| Vol. 1 Issue 3,14 | Winter 2020

Table 2. Some population Densities and Trajectories 2010-2015

\begin{tabular}{|c|c|c|c|c|}
\hline \multicolumn{5}{|c|}{ Some Population Densities and Trajectories 2010 -2050 } \\
\hline Country & $\begin{array}{l}\text { Density } \\
\text { (people/ } \\
\text { knm }^{2} \text { ) }\end{array}$ & 2010 & 2050 & $\begin{array}{c}\text { Change } \\
(\%)\end{array}$ \\
\hline India & 369 & $1,214,464,000$ & $1,613,800,000$ & 33 \\
\hline Canada & 3 & $33,890,000$ & $44,414,000$ & 31 \\
\hline $\begin{array}{l}\text { United } \\
\text { States }\end{array}$ & 33 & $317,641,000$ & $403,932,000$ & 27 \\
\hline Iceland & 3 & 329,000 & 407,000 & 24 \\
\hline Norway & 13 & $4,855,000$ & $5,947,000$ & 22 \\
\hline $\begin{array}{l}\text { United } \\
\text { Kingdom }\end{array}$ & 255 & $61,899,000$ & $72,365,000$ & 17 \\
\hline Mexico & 57 & $110,645,000$ & $128,964,000$ & 17 \\
\hline Swreden & 21 & $9,293,000$ & $10,571,000$ & 14 \\
\hline Spain & 90 & $45,317,000$ & $51,260,000$ & 13 \\
\hline Brazil & 23 & $195,423,000$ & $218,512,000$ & 12 \\
\hline China & 141 & $1,354,146,000$ & $1,417,054,000$ & 5 \\
\hline Netherlands & 401 & $16,653,000$ & $17,399,000$ & 4 \\
\hline Finland & 16 & $5,346,000$ & $5,445,000$ & 2 \\
\hline Denmark & 127 & $5,481,000$ & 41 & 1 \\
\hline Italy & 199 & $60,098,000$ & & -5 \\
\hline South Korea & 487 & $48,501,000$ & & -9 \\
\hline Germany & 230 & $82,057,000$ & & -14 \\
\hline Russia & $\mathbf{s}$ & $140,367,000$ & & -17 \\
\hline Japan & 336 & $126,995,000$ & 56 & -20 \\
\hline
\end{tabular}

Source: Smith (2011)

Table 2. Resource reallocation trends on a global scale up to 2050

\begin{tabular}{|c|c|c|c|c|c|c|}
\hline \multicolumn{7}{|c|}{$\begin{array}{l}\text { Some Common MTeasure of Economic Globalization, } \\
\text { Peacefulness, and Civil Liberties, Relative to the World }\end{array}$} \\
\hline \multicolumn{7}{|c|}{ Economically globalizing? Peaceful? Political freedoms? Average Score } \\
\hline $\begin{array}{l}\text { WSJ/ } \\
\text { Heritage }\end{array}$ & EWF & $\begin{array}{c}\text { KOF } \\
\text { Globalization }\end{array}$ & GPI & EIUDI & $\begin{array}{c}\text { Freedom } \\
\text { House }\end{array}$ & $\begin{array}{c}\text { WVSJ/ } \\
\text { Heritage }\end{array}$ \\
\hline Denmark & 96 & 91 & 97 & 99 & 97 & Free \\
\hline Canada & 96 & 95 & 96 & 94 & 93 & Free \\
\hline Finland & 91 & 90 & 94 & 94 & 96 & Free \\
\hline Iceland & 92 & 91 & 83 & 97 & 98 & Free \\
\hline Norway & 84 & 84 & 90 & 99 & 99 & Free \\
\hline Sweden & 85 & 77 & 97 & 96 & 99 & Free \\
\hline $\begin{array}{l}\text { United } \\
\text { States }\end{array}$ & 97 & 94 & 82 & 42 & 89 & Free \\
\hline Russia & 18 & 28 & 79 & 6 & 36 & not free \\
\hline Germany & 86 & 88 & 89 & 89 & 92 & Free \\
\hline $\begin{array}{l}\text { United } \\
\text { Kingdom }\end{array}$ & 94 & 96 & 87 & 76 & 87 & Free \\
\hline Japan & 89 & 81 & 66 & 95 & 90 & Free \\
\hline France & 64 & 68 & 92 & 79 & 86 & Free \\
\hline Brazil & 41 & 32 & 62 & 41 & 75 & Free \\
\hline India & 31 & 45 & 41 & 15 & 79 & Free \\
\hline China & 26 & 34 & 56 & 49 & 19 & not free \\
\hline
\end{tabular}

Source: Smith (2011) 


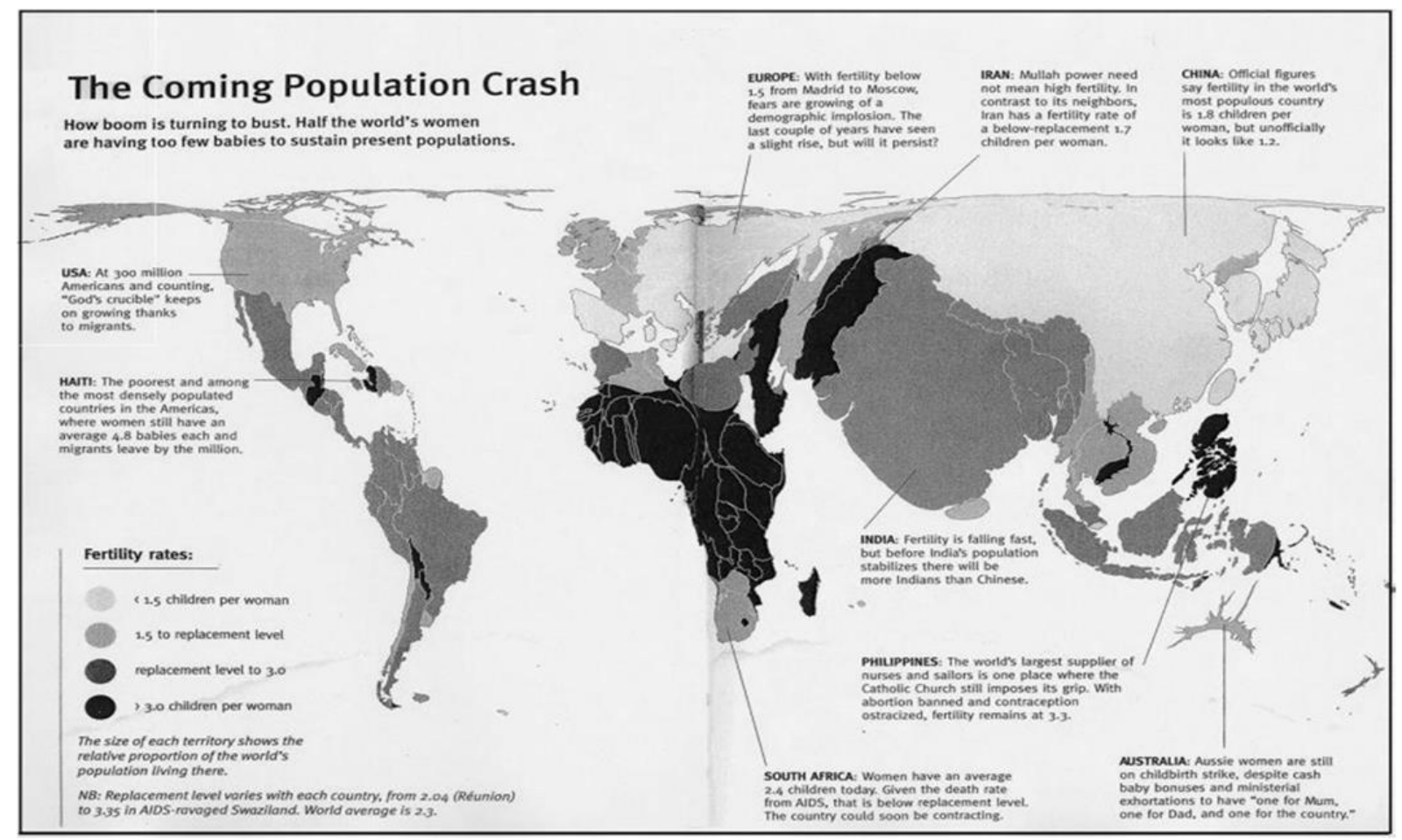

Figure 2. Pearce's Population Crash Hypothesis. Pitasi's elaboration from Pearce (2010)

\section{Methodological Framework}

Hypercitizenship theory and policy model have been developed in several writings specifying its four multidimensional complexity through a systemic and process centered epistemology.

a) Cosmopolitan (Beck, 2006) "Cosmopolitanism [...] is a vital theme of European civilization and European consciousness and beyond that of global experience" (Beck, 2006, 2).

b) Scientific (Nowotny, 2008) "A knowledge-based society also increases its production of epistemic things, various kinds of abstract objects, and technical artifacts that are subject to the same rules". The democratization of scientific expertise is also merely the expansion of the principle of governance that has served the Western liberal democracies well. Today, science and technology are no longer viewed with awe but are part of everyday life. Mediated by the educational system and the qualifications and certificates people acquire, they determine people's chances for upward social mobility, their working world, and the course of their biographies. It is thus logical to extend the concept of citizenship to science and technology. "Scientific citizenship comprises rights and duties and asks about both the functions that an expanded concept of citizenship could fulfill in social integration and also the duties that arise from it for citizens as well as for political institutions and administration [...]" (Nowotny, 2008, 20).

c) Societarian (Donati, 1993, 2010) Implying the capability of citizens and social networks to generate and shape organizations aimed at letting new social forms emerge by linking lobbying and charity. 
d) Entrepreneurial "Europe lacks neither of ideas nor of entrepreneurs, but European history has got two possible perspectives, both discouraging. Those who have ideas will encounter the knowledge filter, facing which they will either give up and nothing will come up of their ideas, or they will find opportunities outside European borders. Either way or the other, Europe loses" (Audretsch, 2007, 162). This kind of citizenships are also labeled in Heideggerian terms as Gegnet/Vollendung (Schurmann, 1987) coding in which "entropy provides (...) the absolute limit of social system development" (Stepanic et al., 2005, 859) while "social free energy $\mathrm{F}$ is amount of resources that can be extracted from a social system without significa nt changes of its structure" (Stepanic et al., 2005,862).

The hypercitizenship concept is focused on the fact, that systemic communication about key challenges of our times is increasingly meaning communication and public understanding of science and technology for governance and policymaking. From this point of view, law becomes one of the à la carte products which can be bought by browsing a global catalogue (Mundus) surfing on a technological global platform (Globus) of which the Internet can be seen as the most important platform for convergence developments and as a driver of numerous, key, changes. This new media platform is intrinsically global and cosmopolitan, the concept of cosmopolitan vision is a key contribution by U. Beck (2006). The author brilliantly adds that: "what do we mean then by the cosmopolitan outlook? Global sense, a sense of boundarylessness. An everyday, historically, alert, reflexive awareness of ambivalence in a milieu of burying differentiation and cultural contradictions" (Beck, 2006: 3). As a matter of fact, the cosmopolitan outlook can be featured as follows: as a counterimage to the territorial prison theory of identity, society and politics. "We can provisionally distinguish five interconnected constitutive principles of the cosmopolitan outlook:

- First, the principle of experience of crisis in world society: the awareness of interdependence and the resulting civilizational community of fear induced by global risks and crisis which overcomes the internal and external boundaries, us and them, the national and the international boundaries.

- Second, the principle of recognition of cosmopolitan differences and the resulting cosmopolitan conflict character and the (limited) curiosity concerning differences of culture and identity.

- Third, the principle of cosmopolitan empathy and of perspective taking and the virtual interchange ability of situations (as both an opportunity and a threat).

- Fourth, the principle of the impossibility of living in a world society without borders and there consulting compulsion to redraw old boundaries and rebuild old walls.

- Fifth, the mélange principle: the principle that local, national, ethnic, religious and cosmopolitan cultures and traditions interpenetrate, interconnect and interminglecosmopolitanism without provincialism is empty, provincialism without cosmopolitanism is blind" (Beck, 2006: 7).

While the mass media often still fall into the methodological nationalism (Beck, 2006), trap which Beck describes as: the cosmopolitan outlook calls into question one of the most powerful convictions concerning society and politics which find expression in the claim that modern society and modern politics can only be organized in the form of national states. Society is equated with society organized in nationally and territorially delimited states. When 
social actors subscribe to this belief, I speak of a national outlook. When it determines the perspective of the scientific observer I speak of methodological nationalism. (Beck, 2006: 24).

\section{Towards a hypercitizen indicator system}

Hypercitizenship and its four reconfiguration dimensions generates a re-entry of nationalism and provincialism as memes (Dawkins, 1976), among many others, of the Mundus Catalogue recombining memetic sets to be browsed through the Globus by the hypercitizen.

The hypercitizen indicator are:

- CI cosmopolitan index

- SI scientific index

- EI entrepreneurial index

- LI lobbying + charity index

- Gegnet VARIETY (= social free energy) Vollendung

- $\operatorname{DENSITY(=~social~entropy)~}$

- CI: Memetic recombination

- VERSUS Cultural tradition

- SI: Multiple IP streams of income

- VERSUS Bureaucratized IP ownership

- EI: Multiple streams of Income

- VERSUS Verticalization of wages

- LI: Persistence, strange, abstract

- VERSUS Insistence, familiar, emotional

An HC indicator system is complex if Variety (V)/Density (D) $>3$ If $\mathrm{V} / \mathrm{D}=3$ or V/D $<3$ the system is complicate, not complex thus it is featured by a high paralyzing density of copies and requires high selective (in quantity) and random (in quality as they are copies) operations.

Methodologically speaking, hypercitizenship (HC) may be formulated as follows:

$\mathrm{HC}=\mathrm{CI}+\mathrm{SI}+\mathrm{EI}+\mathrm{LI}$ which is mathematically a functional equivalent of Macroeconomics fundamental formula GDP=C+G+I+NX (Constable and Wright, 2011, xvi) thus the four HC dimensions or indexes shape the conceptual frame to construct the HC indicators system. Nevertheless, GDP's "D" expressed a methodological nationalism inspired by domestic balance while HC is something to be conceptualized, categorized and measured according to global trends and transnational flows: metaphorically, GDP is a black and white photograph, $\mathrm{HC}$ is a colour movie. The construction of an $\mathrm{HC}$ indicator system implies a methodological design founded on artificial simulation models framed into logical-deductive theorems and tested through big data patterns and convergences which for example demonstrate that expansion of the birth rate is not the alternative to the aging trend (https://www.un.org/development/desa/pd/sites/www.un.org.development.desa.pd/files/files/d ocuments/2020/Jan/un_2001_nationalpopulationpolicies.pdf). Operationalizing concepts into definitions to set the indicator system, requires a logic-deductive formalization shaped as a theorem. The social free energy (Gegnet)/social entropy (Vollendung) coding redesigns the concept - definition - indicator - variable sequence about global evolution. The HC indicator 
system challenges this loop I call the human heritage bankruptcy but the HC indicator system is linked to a systemic theorem of global evolution which is provided as an exemplary case. Designing hypercitizenship, methodological toolkit implies to evolve systemic strategic thinking both epistemologically and for policy making and this essay dealt with both levels also by providing an exemplary case of the convergence of epistemology and policymaking is pivotal to cope with complex systemic challenges of our times. The next step, in a further essay, will be to enter the technical level of $\mathrm{HC}$ indicators derived from the formula: $\mathrm{HC}=\mathrm{CI}$ $+\mathrm{SI}+\mathrm{EI}+\mathrm{LI}$ discussed in this work.

The world order is becoming more and more convergent through turbulent non linear trends nevertheless convergence is a clear trend as witnessed by some key agreements signed for example by the European Union with most part of the planet since February 2017 at least with Canada (as a stargate to NAFTA), Japan, Singapur and Mercosur. As every research and paper need a paradigm and a perspective, this paper is written in European Union perspective, scientifically neutral to provide info and data hypothetically providing science based policy guidelines for the EU in its next evolution which implies two key aspects:

1. the management of state members, eventually exiting state members (as of today hypothetically UK which is still a member) and of would be state members which as of today are Albania, North Macedonia, Montenegro, Serbia and Turkey. Turkey is our case for the reasons discussed in the next paragraph

2. the EU a s a global player in a global, cosmopolitan, open scenario of free circulation of .... everything or almost through a global expansion of worldwide treaties.

In this paper, we will be focused on the first aspect through a specific case study to which we will apply the hypercitizen index.

\section{Turkey Candidacy as a EU Member State}

Ever since 1923, foundation of modern Turkey, the policy-makers have followed a policy of westernization, with the objective to reorganize the Turkey's society and redefine its place in the world and its application for EC membership in 1959 reflected these goals. Two factors specifically worked against an immediate opening of accession negotiations:

- the EC was preoccupied with the establishment of a Single Market by 1992 and remained reluctant to welcome any new members in the meantime.

- Starting from the mid-1980s, Turkey fought an increasingly bloody Kurdish insurrection in South-East Anatolia and faced accusations over the abuse of human rights and the rights of minorities.

The EC proposed some measures to intensify EC-Turkish relations since raised reservations about Turkey's ability to implement the necessary social, political and economic adjustments required for EC membership in the medium term. The following four, are the measures designed to re-launch relations with the EC:

- The intensification of financial cooperation,

- the completion of the c industrial union,

- technological cooperation,

- the strengthening of political and cultural links.

So, meeting these measures, Turkey was well on its way to meet most of the requirements the 
EU had set for the beginning of accession negotiations, but in the next years several issues, as the motion adopted by the Turkish Parliament that authorizes the government to intervene military against PKK fighters in northern Iraq or other issues as the fight against corruption, judicial reform, trade union rights and women's and children's rights - also, in the meantimeTurkey needed to create conditions in the south-east part of the country for the Kurdish population to enjoy full rights and freedom, have slowed down progress and Turkey would need to make significant further efforts in the field of freedom of expression and the rights for non-Muslim religious communities.

However, the growing hostility from the side of the EU and a feeling of deception on possible membership, made Turkish enthusiasm for membership plunge and only a quarter of the population thinks that their country will ever become a member, but in the meantime Turkey's economy is facing several challenges, such as high unemployment and high inflation. Strong economic volatility has undermined the business environment and overreliance on external financing has created vulnerabilities (Paolone and Pitasi, 2013).

This situation allows us to hypothesize four possible adjacent (Kaufmann, 2000) future scenarios regarding the course of Turkish re-accession negotiations:

Under the first scenario, economic reforms in EU member states continue to deepen and economic growth strengthens, leading to a long-term economic revival of continental European countries. At the same time, EU member states successfully agree to implement a package of institutional and procedural reforms, enabling the further enlargement of the EU. Under these conditions, it seems possible that popular disenchantment with enlargement would cede and that demographic pressure could convince EU member states to admit Turkey, once it has fulfilled all ascribed criteria. In the current political mood, this scenario seems highly unlikely.

In a second scenario, economic reforms in Europe run into the sand, or exaggerate the existing economic malaise. Conflict over the appropriate way ahead prevents any ambitious reshape of EU institutions, making the EU increasingly unable to make common decisions, not in the least about future enlargements. Under these conditions, public opinion would most likely grow even more opposed, and Turkish ambitions are doomed to fail in the Austrian and French referenda. However, given this situation, it seems probable that negotiations would be broken off at an earlier stage and that Turkey could be offered a "privileged partnership" with the EU, possibly granting it access to some of the EU common policies. However, it is unlikely that Turkey would ever accept such a status.

Under a third scenario, Turkey implements in full the necessary reforms qualifying it for EU membership. Economic reforms and FDI lead to a boom in the Turkish economy and Turkey develops into a regional growth center and considerable regional power. Over the same period, growth in Europe remains low and continuing intra-European disputes mean that Europe fails to establish itself as a global actor of any weight. Given these circumstances, it seems possible that Turkey, a country with a strong sense of sovereignty and its own imperial history, would reject membership of the EU and instead opt for a "privileged partnership", under which it is granted certain rights and prerogatives.

In the final scenario, a violent rejection of the European project occurs from within part of Turkish society, leading to a rejection of EU membership. It seems perceivable that such a rejection could either emerge from the ranks of the Turkish military or Turkey's political 
Islamists. In case of the military, a renewed Turkish- Kurdish military conflict could lead to the roll-back of certain reforms and a new era of military control. On the other hand, it is possible that the Islamist establishment grows increasingly discontent with what it perceives as European anti-Muslim discrimination and chooses to no longer pursue EU membership. In the latter case, it could of course be possible that, a secular party will take over from the AKP, and the pursuit of the EU project will continue.

Seen, on the whole, one of the biggest economic challenges for Turkey is to make its recent macroeconomic stabilization sustainable. Of utmost importance in this respect is a significant catch-up in the quality of institutions and governance to the EU level. Hence, one important policy conclusion would be to link up pre-accession financial support with the accumulation of human capital instead of the usual support for standard infrastructure projects.

If Turkey is able to stick strictly to its reform-oriented path of modernization, nothing can prevent us from expecting enormous benefits from the integration of two regions with significantly different factor endowments.

\section{The need for structural coupling between Turkey and the European Union}

Modern Turkey was established at the site of the former "sick man" of Europe, the Ottoman Empire. Together with the Allies of the Ottoman Empire, the German Empire, and the AustroHungarian Monarchy, the country emerged as a loser from the First World War. The defeat pushed Germany into despair and destroyed the Austro-Hungarian Monarchy. Instead of the Monarchy, a small German-populated Austria and a significantly reduced Hungary were established.

Initially, the situation in the Ottoman Empire was similar. The Sultan, Mehmed VI signed the Peace Treaty of Sevres on 10th August, 1920, which severely mutilated the area of state as did the peace treaties signed with the Austrians on 10th September, 1919 in Saint-Germain and the Hungarians on 4th June, 1920. But, while the Austrians and the Hungarians made no serious attempt to conquer their lost territories and citizens back, the army of the Ottoman Empire did not resign to the mutilating terms of the Peace Treaty of Sevres and started fights to keep certain parts of the Empire in Europe and Asia. The fight led by Kemal Ataturk was not without success. On 24th July, 1923, the Empire concluded a new peace treaty that resulted in it retaining control of the Bosphorus, regaining full Anatolia, and retaining East Thrace, Smyrna and the vicinity of Istanbul.

The new, successful peace treaty greatly facilitated the radical transformation of the dilapidated political structure of the Ottoman Empire. On October 29, 1923, the republic was proclaimed, the Sultan together with his sibling was exiled. The Republic was organized on the basis of the textbook principles of the modern nation-states that developed in Western Europe (Kedourie, 1993). The church was separated from the state. The people deprived of the security of their religious identity had to find their identity through national education provided by the state. The Turkish nation-state was formed quickly and efficiently.

Kemalism is a model of Western nation-building that bravely breaks with Islamic social philosophy in the name of enlightenment. Kemalism successfully created the secular Turkish Republic with its pillar being the "Turkish" identity of its citizens, which draws its strength from language, culture, and traditions. 
Kemalism successfully survived World War II, protecting Turkey from another war adventure. In Europe, attempts to create illiberal societies failed one after the other. National Socialism, Fascism, Phalangism came to an end and the glory of the Leninist-Stalinist Socialism also faded away. Kemalism is an example of a top-down liberal social transformation that appeared to be successful for a long period of time.

However, the Turkish nation-state only apparently became like the nation-states of Europe (Huntington, 1996). National homogenization, promoted by Kemalism, was only possible through the strengthening of the state, which brought about intolerance to minorities and forced assimilation.

Turkish society was unevenly modernized. The life of Izmir and Istanbul follows Western standards, while attraction to the Islam revives in Inner Anatolia. The elite frustrated by the upcoming problems of joining the European Union is chasing the phantoms of the Ottoman Empire.

It is both an opportunity and a responsibility of the European Union to attract the Republic of Turkey to the western liberal nation-states. The Republic of Turkey can make a significant contribution to increasing Europe's economic, demographic and cultural weight in the world. The Republic of Turkey will only be able to withstand the ideological ghosts of the past if it assimilates the values contained in the Charter of Fundamental Rights of the European Union, which can send Turkish citizens on their way towards the solutions of hypercitizenship.

Chapter 1 of the Charter of Fundamental Rights summarizes the rights that are indispensable to experiencing human dignity; these rights include the prohibition of torture, inhuman or degrading treatment or punishment and the elimination of slavery and forced labor. Chapter 2 is a catalogue of liberties. The pillar of a successful society is a person protected by freedom of property, enterprise, and thought. Chapter 3 includes the prohibition of discrimination. The Chapter 4 emphasizes solidarity. Chapter 5 deals with civil rights. Chapter Six sets out the judiciary framework in states under the rule of law.

The rights laid down in the Charter of Fundamental Rights effectively protect citizens against the power of the state, while freeing them to build the state, serve the interests of the community and maintain justice between the generations.

Compromise between Turkey and the European Union is in the interest of both parties, but it will only be realized if the will to compromise permeates all dimensions of relations between the Republic of Turkey and the European Union. The political dimension is important but not sufficient. The same is true about the economic dimension. Joint ventures, mutually beneficial economic relationships can become a solid basis for understanding. Strengthening cultural and educational relations can make a significant contribution to the accession of the Republic of Turkey to the European Union. The most important thing to be done would be to strengthen folk diplomacy.

Ernes Renan once said that "The existence of a nation (you will pardon me this metaphor) is a daily referendum." (Renan, 1996). These words can also be used to refer to a community that bridges national, religious, gender, ethnic, and age categories, driven by hypercitizenshipbased identity.

Reconciliation with Turkey is only the first step to increase Europe's role in the world. Europe's eastern neighbor is Russia, which since Peter the Great has been experimenting with 
the incorporation of European social building methods into Russian society. The Russian Federation is a successful example of a political entity based on respect for diversity, which the European Union is also experimenting with.

The European Union will only be able to cope with the challenges of globalization if, having created the infrastructure of hypercitizenship, building on the benefits provided by talent, patience, and technology, it takes the initiative and opens up towards the future in the spirit of innovation, discovery and critical thinking.

Volatility, uncertainty, complexity, and ambiguity that has always been present in the world has increased at an unprecedented rate in the 21 st century. Today, the huge, yet separate, competing nations and international economic enterprises are no longer sufficient to meet the challenges facing humanity. Ulrich Beck was well aware that changes affect the whole world and risk management is only possible at a global level (Beck, 1998).

A well-thought-out economic, cultural and ideological expansion of the European Union can be a competitive advantage in the competition between world powers. The people living in Europe need to ask themselves whether they want Europe to be one of the world's leading powers or, rather, they let Europe drift towards the end.

If the Europeans want to give up the vain hope of escape by chance, then they have no other choice than the attitude to oppose knowledge, questioning and confrontation with the whole, which the ancient Greek philosophers left for us at the dawn of Western thought. Modern-age technical-mathematical thinking has advanced mankind far in both destruction and construction. Modern-age technical-mathematical thinking has advanced mankind far in both destruction and construction. However, even artificial intelligence, the form of existence webbing the whole of the economic-cultural-social way of life is not able to go beyond the beginnings. Heidegger, who was otherwise born at an inappropriate time, in his rightly controversial rector's speech, unarguably states that "the beginning still is. It does not lie behind us, as something that was long ago but stands before us. As what is greatest, the beginning has passed in advance over all that is to come and thus already over us as well. The beginning has invaded our future. There it stands as the distant command to us to catch up with its greatness." (Heidegger, 1933). Bringing Turkey closer to Europe could be the first step on the road to greatness.

\section{Epilogue. Hypercitizenship Index in action Some Policy Guidelines}

Noise reduction and constriction of meaning in the World Order Policy Modelling (WOPM) are pivotal to draw viable distinctions among concepts and principles / facts / perceptions and emotional contingent shifts. The differences which can really make the difference in the potential entrance of Turkey in the EU are listed below free from any moral, ethical judgement. The differences which make the difference about Turkey's entrance from the EU 's perspective. The number one is the pillar, the further seven ones are corollaries:

A1. The entrance of Turkey in the EU would mean an increase of density, variety and complexity of the EU itself.

A2. The entrance of Turkey i the EU would mean an expansion and stabilization of the EU in the South East totally revising the immigration policy by land through Turkey which is currently a closed stargate of immigration nevertheless at this moment Turkey in an independent foreign stargate while as an EU member state EU might take control in that area. 


\section{A3. Also designing new diplomatic spaces with the Russian Confederation.}

A4. Turkey as an EU state member would re-localize some important brand's production inside the EU also contributing to balance ILO decent job standards and lower production costs to let EU more competitive on the global markets.

A5. Turkey, as seen above in paragraph 5, is a raising global giant in ecommerce and to let it be it from inside the EU it would allow EU to improve its Made in the EU brand and world class distribution and web promotion.

A6. Turkey was among the 48 original sates undersigning the 1948 UN Human Rights Declaration and thus according to the validity principle of the general theory of law, Turkey is already viable for the EU human rights standards (Treaty of Niece) although it can be at risk of political contingent phenomenon about human rights violation and it is probably the key reason why Turkey is still a candidate and not yet a member state.

(check the negotiations state of art and the list of commitments countries have to meet in order to become a member state)

A7. Turkey is formally and legally a secularized state. No official state religion. The huge part of its citizens are Islamic, nevertheless the state is not, thus in case of entrance no way Turkey might legitimate a legal priority of the Koran on the positive, artificial law of the EU and jo way turkey might legitimate the control of Koran on science either.

A8. Turkey is a big transcontinental, cosmopolitan country whose intangible heritage has been acknowledged and awarded by UNESCO several times. It would be a great expansion of the cosmopolitan enlightenment (Pinker, 2018) which is the root of the EU itself. The differences which make the difference about Turkey's entrance from the Turkey's itself perspective.

A9. Tranconstitutionalism would be a very effective legal shape of cosmopolitanism, improving the legal flexibility of the European Union and in the meantime a soft law unification of the global administrative law including Turkey. It would allow a systemic expansion and a soft, more peaceful and open conception of law (Neves 2009, Teubner 2012 and Thornill, 2016).

A10. Turkey is fighting in the global scenarios taking advantage of the way it is weakening its currency by purpose. Weak currency (which can be monitored in real time at www.xe.com) is a key tool of war currencies dominating our time and hypothetically shaping four potential scenarios (Rickards, 2012).

I) The multicurrency scenario, ours and no longer working as for its high conflict turbulence II) Chaos III) Back to the Gold Standard but why getting back to the past if the past did not work? IV) THE SDR scenario, also suggested by Robert Triffin (1999, past director of the World Bank, in practice letting the World Bank and the International Monetary Fund (IMF) set a standard, formal currency for the whole planet. This seems the direction global political economy is head to, but this way needs stull many steps and to replace the Turkish Lira (TRY) with euro were strategic to reduce global instability, volatility and political economy manipulation as the weakening of a currency is an inflation choice not a "natural and spontaneous" change in a supposed intrinsic value mechanism. Currency inflation can also be a dumping tool in employment costs, import /export strategies and more. 
Pillar:

B1. The entrance of Turkey in the EU would mean an increase of density, variety and complexity of the EU itself

\section{Corollaries}

B2. The entrance of Turkey in the EU would expand the EU borders providing new power to Turkey as legally valid stargate for further would-be EU member states as both the legal and geographical concept of Europe is rather flexible

B3. Turkey is a NATO member and at the same time a very close partner of Russian Confederation. EU project of a EU Army would be radically different if Turkey - whose Army is rather huge- as big as the whole Greek population - were in (is this good to turkey or is it better to the EU?)

\section{B4. Turkey's economy would take off globally as a follow up of A4 and of A5}

B5. With some operational improvement in human rights, the current challenge of Turkey to let the new airport of Istanbul the "hub of the world "would become easily effective both for business and tourism (see A8) and thanks to its current legal shapes (shown in A6 and A7), Turkey is not too far from the goal. The EU should be sensitive during the negotiations to the internal dynamics of this process. In this context, the implementation of the principle of "conditionality" should not be treated as a technical matter; it is a highly politicized matter and has important internal ramifications. It should always be matched with incentives and be sensitive to the internal dynamics of the country. Turkish accession is one of the most challenging cases for the EU. It seems that this process will be a long, contested and a challenging one both for Turkey and the EU. It will be a challenging for Turkey, because Turkey will adopt the multilevel governance system of the EU and will act within the broader context of the EU. Turkey will increasingly define itself within the process of Europeanization in the context of Wider Europe and neighborhood issues. It may take some time but there is a need to increase confidence in the relationship and decrease this ambivalence with the start of negotiations. Turkish accession is one of the most challenging cases for the EU. It is a challenging project for the EU, because it will include a country, which has far a long time considered as the "other" of Europe. However, The EU has faced many challenges in the past and has been successful; it can also meet the present challenge.

Stigmas, commons sense beliefs, labels do not facilitate the European Union- Turkey openings since the 1635 Vienna Siege at least, nevertheless stigmas and labels are often misleading as the one Turkey would be an Islamic state which is not of course. Turkey is a growing political -military entity, instead. Since the entrance of the Turkish tanks in Syria a few months ago, Turkey is expanding its borders and its area of influence in a very clear way generating a paradoxical self-fulfilling prophecy: the fear of a new "Vienna Siege" made the European skeptical about a potential entrance of Turkey in the Union, while waiting for an official European Union response, Turkey expanded outside the Union, the more Turkey expands outside the European Union the more the Union might be scared of emerging Ottoman Empire increasing the risk of a revival of the Vienna Siege. This way the loop of the self-defeating lose /lose self-fulfilling prophecy clearly takes shape. That is why both in case of considering Turkey a friend /allied and an enemy, it was a very risky mistake if the European Union tried to manage the relation with Turkey using distance. 
Let's think, for example, of what is happening in these days, the Turkish President is exasperating the tension with Athens and consequently with Europe, using the TurkishLibyan memorandum, so in addition to the military ships off the island of Kastellorizo, there are the continuous provocations of combat aircraft.

\section{References}

Audretsch D. (2007), The Entrepreneurial Society. Oxford University Press., Oxford.

Beck, U. (1998), World Risk Society. Polity Press, Cambridge.

Beck U. (2006), The Cosmopolitan Vision. Polity Press, Cambridge.

Boatcă M., Gutiérrez Rodríguez E., Costa S. (2016), Decolonizing European Sociology. Transdisciplinary Approaches. London, Routldedge.

Constable S. Wright R.E. (2011), Guide to the 50 Economic Indicators That Really Matter. Harper Business, New York.

Donati P. (1993), La cittadinanza societaria. Laterza, Roma-Bari.

Donati P. (2010), Relational Sociology. Routledge, London.

Dawkins R. (1976), The Selfish Gene., Oxford University Press, Oxford.

Gombrich E. (1985), Custodi della memoria. Feltrinelli, Milan.

Harris J. (2007), Enhancing Evolution., Princeton University Press, Princeton.

Heidegger M. (1933), 'The Self-Assertation of the German University' in Neske G. and Kettering E. (eds.), Martin Heidegger and National Socialism, Paragon House, New York, 1990, pp. 5-13.

Huntington S. (1996), The Clash of Civilizations and the Remaking of World Order.Touchstone, New York.

Lowi T. J. (2009), Arenas of Power, Reflections on Politics and Policy. Routledge, London

Luhmann N. (1988), 'Warum AGIL?', in Kölner Zeitschrift für Soziologie und Sozialpsychologie, 40, 127-139.

Luhmann N. (1989), Ecological Communication. University of Chicago Press, Chicago.

Luhmann N. (1990), Essays on Self Reference. New York, Columbia University Press.

Luhmann N. (1995), Social Systems. Stanford, Stanford University Press.

Luhmann N. (1997), Die Gesellschaft der Gesellschaft. Suhrkamp Verlag, Frankfurt am Main.

Luhmann N. (2010), Soziologische Aufklaerung. Opladen, WestdeutscherVerlag.

Kaufmann S. (2000), Investigations. Oxford, Oxford University Press.

Kedourie, E. (1993), Nationalism. Fourth, expanded edition., Blackwell, Oxford. 
Malthus T. R. (2004), An essay on the Principle of Population. W.W. Norton, New YorkLondon.

Neves M. (2009), Transconstitucionalismo. WMF Martins Fontes, São Paulo

Nowotny H. (2008), Insatiable Curiosity-Innovation in a Fragile Future. MIT Press, Cambridge MA.

Ortega y Gasset J. (1963), Man and People. Norton, New York.

Paolone G. and Pitasi A. (2013), Comparing Systemic Business Paradigms, Chance, Complexity, Communication and Evolutionary Strategies. LAP Lambert Academic Publishing, Saarbrücken.

Pearce F. (2010), The On Coming Population Crash. Beacon Press, Boston.

Pinker S. (2018), Enlightenment Now, The Case for Reason, Science, Humanism, and Progress. Penguin Group, UK.

Pitasi A. (2012), 'Systemic Shifts in Sociology', in Mancini G. and Pitasi A.(eds) Systemic Shifts in Sociology, Lambert Academic Publishing, Saarbrücken.

Pitasi A. and Ferone E. (2008), Il tempo zero del desiderio. McGrawHill, Milano.

Pitasi A. (2011), Le Monde Hyperhumain. L'Harmattan, Paris-Turin.

Pitasi A. (2012a), 'What is sociology for?' in World Futures Journal 68, 221-224.

Pitasi A. (2012b), 'Hypercitizenship and the Management of Genetic Diversity, Sociology of Law and the Key Systemic Bifurcation Between the Ring Singularity and the Neofeudal Age', in World Futures Journal 68, 314- 331.

Pitasi A. (2013), 'The Hypercitizenship Challenge to Methodological Nationalism', REDES Revista Eletrônica Direito e Sociedade, Centro Universitário La Salle - UniLasalle.

Pitasi A. and Mancini G. (2011), Systemic Shift in Sociology. LAP Lambert Academic Publishing, Saarbrücken.

Plüss C. (2013), 'Migrants Social Positioning and inequalities. The Intersections of Capitals, Locations and Aspirations', in International Sociology, 28(1), 4-11.

Renan E. (1996) 'What is a Nation?' in Eley G. and Suny R.G. (ed.) 1996, Becoming National, A Reader, Oxford University Press New York and Oxford, 41-55. See especially pp. $52-54$.

Rickards J. (2012), Currency Wars, the making of the next global crisis. Penguin, London.

Rose N. (2009), La politica della vita. Einaudi, Turin.

Smith LC.( 2011) The World in 2050. Penguin, London..

Stepanic J., Sabol G. and Zebec M.S. (2005), Describing Social Systems using free social Energy and social entropy in Kybernetes 34(6), 857-868.

Teubner G.(2012), Nuovi conflitti costituzionali. Bruno Mondadori, Milano

Thornill C.(2016), A Sociology of Transnational Constitutions, Social Foundations of the Post-National Legal Structure. Cambridge University Press, Cambridge 
WORLD COMPLEXITY SCIENCE ACADEMY JOURNAL| Vol. 1 Issue 3,14 | Winter 2020

Toffler A. and Toffler H. (2006), Reviolutionary Wealth. Doubleday, London.

Triffin R. (1990), Dollaro, euro, moneta mondiale. Il Mulino, Bologna

Xiaoying Q. (2012). 'A Case Study of Globalized Knowledge Flows, Guanxi in Social Science and Management Theory' in International Sociology 27(6) 707-723.

This article is distributed under the terms of the Creative Commons Attribution 4.0

License (https://creativecommons. org/licenses/by/4.0/) which permits any use, reproduction and distribution of the work without further permission provided the 
WORLD COMPLEXITY SCIENCE ACADEMY JOURNAL| Vol. 1 Issue 3,14 | Winter 2020

original work is attributed as specified on the WCSA Journal by World Complexity Science Academy (https://www.wcsaglobal.org/ethics-policy/). 